Jurnal Health Sains: p-ISSN : 2723-4339 e-ISSN : 2548-1398

Vol. 2, No. 2, Febuari 2021

\title{
PEMAHAMAN REMAJA TENTANG KESEHATAN REPRODUKSI DAN TINJAUAN YURIDIS PERKAWINAN USIA DINI
}

\section{Nung Ati Nurhayati}

Akademi Keperawatan Rumah Sakit Dustira, Cimahi, Jawa Barat, Indonesia

Email: nungatinurhayati@gmail.com

\begin{tabular}{l} 
ARTIKEL INFO \\
\hline Tanggal diterima: 5 Februari \\
2021 \\
Tanggal revisi: 15 Februari \\
2021 \\
Tanggal yang diterima: 25 \\
Februari 2021
\end{tabular}

Keywords:

Adolescents; reproductive health; early marriage

Kata Kunci:

Remaja; kesehatan

reproduksi; perkawinan dini

\begin{abstract}
Adolescence is the most difficult period that every individual must go through which will determine the phases of subsequent life development. The main problem in adolescent's life is reproductive health problems related to sexuality. Several studies have shown that adolescents' understanding of reproductive health is still low, especially related to casual sex behavior. The low understanding of reproductive health has resulted in a lack of understanding of early childhood marriage, which is still a fairly high number in Indonesia. The purpose of this study was to examine how adolescents' understanding of reproductive health and how the juridical review of early age marriage is seen from undang-undang no 1 tahun 1974 tentang perkawinan. The review using a systematic review follows the Optional Guide for Sytematic Review and Meta Analyzes (PRISMA) reviews using a flowchart based on the PRISMA 2009 checklist. Low knowledge of adolescents about adolescent reproductive health has an impact, such as an increase in the rate of early marriage. Due to the juridical consequences of underage marriage, there is no apparent violation of Undang-Undang No 16 tahun 2019 sebagai perubahan atas Undang-Undang No 1 tahun 1974 tentang perkawianan, but there are other juridical consequences, namely neglect in the household which can be subject to criminal threats according to Undang-Undang No 23 tahun 2004 tentang Kekerasan Dalam Rumah Tangga, in the event of a divorce it will result from the law of neglect of children resulting in violations of Undang-Undang No 35 tahun 2014 sebagai perubahan atas Undang-Undang No 23 tahun 2002 tentang perlindungan anak..
\end{abstract}

\begin{abstract}
ABSTRAK
Masa remaja merupakan masa tersulit yang harus dilalui setiap individu yang akan menentukan fase-fase perkembangan kehidupan selanjutnya. Masalah utama dalam kehidupan remaja adalah masalah kesehatan reproduksi yang berkaitan dengan kehidupan seksualitas. Beberapa penelitian menunjukkan bahwa pemahaman remaja tentang kesehatan reproduksi masih rendah terutama terkait dengan perilaku seks bebas. Rendahnya pemahaman tentang kesehatan reproduksi berdampak pada kurangnya pemahaman tentang
\end{abstract}




perkawinan usia dini yang sampai saat ini masih menduduki
angka yang cukup tinggi di Indonesia. Tujuan penelitian ini
untuk menkaji bagaimana pemahaman remaja tentang
kesehatan reproduksi dan bagaiman tinjauan yuridis
perkawinan usia dini dilihat darai Undang-Undang No 1
tahun 1974 tentang Perkawinan. Tinjauan menggunakan
sistematik review mengikuti Panduan Pilihan untuk ulasan
Sytematic Review dan Meta Analyses (PRISMA) dengan
menggunakan flowchart berdasarkan daftar periksa
PRISMA 2009. Rendahnya pengetahuan remaja tentang
kesehatan reproduksi remaja menimbulkan dampak seperti
meningkatnya angka perkawinan usia dini. Akibat yuridis
dari perkawinan di bawah usia, tidak tampak terjadinya
pelanggaran terhadap Undang-Undang Nomor 16 tahun
2019 sebagai perubahan Undang-Undang Nomor tahun
1974 secara jelas, tetapi timbul akibat yuridis lain, yaitu
terjadi penelantaran dalam rumah tangga yang bisa dikenai
ancaman pidana sesuai UndangUndang Nomor 23 tahun
2004 tentang Kekerasan Dalam Rumah Tangga, jika terjadi
perceraian akan timbul akibat hukum terlantarnya anak
sehingga terjadi pelanggaran terhadap Undang-undang
Republik Indonesia nomor 35 tahun 2014 tentang perubahan
atas undang-undang nomor 23 tahun 2002 tentang
perlindungan anak

Coresponden Author:

Email: nungatinurhayati@gmail.com Artikel dengan akses terbuka dibawah lisensi

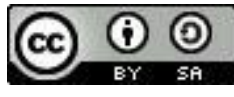

\section{Pendahuluan}

Masa remaja merupakan masa tersulit yang harus dilalui seorang individu. Remaja merupakan masa paling kritis yang akan menentukan fase-fase perkembangan kehidupan selanjutnya (Fitriani et al., 2020).

Berdasarkan data dari badan pusat statistik tahun 2019 jumlah remaja di Indonesia (umur 10-19 tahun) perempuan sebanyak 22.120,000 dan remaja laki-laki sebanyak 23.231.000 Berdasarkan proyeksi penduduk pada tahun 2015 menunjukan bahwa jumlah remaja (usia 10-24 tahun) indonesia mencapai lebih dari 66,000,000 atau $25 \%$ dari jumlah Penduduk Indonesia 255 juta (Bappenas, 2013). Artinya, 1 dari setiap 4 orang Penduduk Indonesia adalah remaja. WHO mendefinisikan remaja dengan Jurnal Health Sains Vol. 2, No. 2, Februari 2021 peralihan dari masa kanak-kanak ke masa dewasa dengan Batasan usia 10 sampai 19 tahun (DAC, 2020). Kementerian Kesehatan Indonesia mendefinisikan remaja dengan Batasan usia 10 sampai 19 tahun dan belum kawin. Sementara menurut BKKBN (Direktorat Remaja dan Perlindungan Hak Reproduksi), batasan usia remaja adalah 10 sampai 19 tahun (Fitriani et al., 2020).

Masalah utama dalam kehidupan remaja yang menjadi sorotan adalah kehidupan seksualitas, karena didorong oleh sifat remaja yang memiliki rasa ingin tahu yang tinggi (high curiousity), yang seringkali menyebabkan usaha untuk mencari dan berpetualang mencoba dan menjelajah terhadap apa yang belum pernah dialaminya. Dorongan ini menimbulkan rasa penasaran 
remaja yang akhirnya mencoba melakukan apa saja termasuk yang sering dilakukan orang dewasa berkaitan dengan masalah seksualitas. Oleh karena itu, seksualitas dianggap sebagai masalah utama dalam perkembangan kehidupan remaja (Ali et al., 2006).

Kehidupan seksualitas remaja berkaitan erat dengan kesehatan reproduksi. Kesehatan reproduksi merupakan salah satu usaha untuk mewujudkan remaja sehat menuju masa depan yang kuat. Hal ini tercantum dalam (UU RI No 36 tahun 2009 tentang Kesehatan pasal 71 menjelaskan : "Kesehatan reproduksi merupakan keadaan sehat secara fisik, mental, dan sosial secara utuh, tidak semata-mata bebas dari penyakit atau kecacatan yang berkaitan dengan sistem, fungsi, dan proses reproduksi pada laki-laki dan perempuan". Hak reproduksi merupakan hak asasi manusia, pemenuhannya merupakan bentuk perlindungan bagi setiap individu, serta prakondisi untuk memperoleh hak-hak lainnya tanpa diskriminasi (Syafikarani, 2018).

Pelayanan Kesehatan reproduksi remaja tercantum dalam PP no 61 tahun 2014 BAB 1 Pasal 1 pelayanan Kesehatan reproduksi remaja adalah salah satu kegiatan dan/atau serangkaian kegiatan yang ditujukan kepada remaja dalam rangka menjaga Kesehatan reproduksi. Bagian kedua pasal 11: (1) pelayanan Kesehatan reproduksi remaja bertujuan untuk a). mencegah dan melindungi remaja dari perilaku seksual berisiko lainnya yang dapat berpengaruh terhadap Kesehatan Repsoduksi Remaja, dan b) mempersiapkan remaja untuk menjalani kehidupan reproduksi yang sehat dan bertanggungjawab.

Sebagai wujud dari Hak asasi manusia maka kesehatan reproduksi ini harus betulbetul dipahami oleh remaja sejak dini untuk mempersiapkan masa depan sebuah bangsa, karena ketika bicara tentang reproduksi berarti kita membicarakan sebuah proses biologis dari kehidupan individu untuk menghasilkan individu baru. Kesehatan reproduksi remaja merupakan kondisi kesehatan yang menyangkut masalah kesehatan organ reproduksi, yang kesiapannya dimulai sejak usia remaja dimana organ reproduksi sudah mampu melaksanakan fungsinya dengan ditandai oleh haid atau biasa disebut menstruasi pertama kali pada remaja perempuan atau mimpi basah bagi remaja lakilaki.

Namun kenyataannya pemahaman remaja tentang kesehatan reproduksi belum menunjukkan hasil yang memuaskan, beberapa penelitian menunjukkan bahwa pemahaman remaja tentang kesehatan reproduksi masih rendah terutama terkait dengan perilaku seks bebas seperti yang dikemukakan Intan Zainafre dalam jurnalnya "Perilaku Seksual dan Implikasinya terhadap Kebutuhan

Layanan Kesehatan Reproduksi Remaja di Lingkunga Kampus (Studi Kasus Pada Mahasiswa Universitas Negeri Semarang), (2015) sebanyak $12,1 \%$ remaja memiliki perilaku sesksual berisiko ditandai dengan pernahnya melakukan aktivitas seksual berupa kissing, necking dan petting dan pada akhirnya perilaku-perilaku tersebut mendorong terjadinya perilaku seksual berisiko PMS dan KTD yaitu dengan melakukan intercourse.

Penelitian yang dilakukan oleh Puti Sari Hidayangsih dengan judul "Perilaku Berisiko dan Permasalahan Kesehatan Reproduksi pada Remaja" menjelaskan bahwa pengetahuan remaja tentang kesehatan reproduksi masih rendah. Hal ini terlihat dari pemahaman remaja yang masih kurang dan perilaku remaja yang masih sangat berisiko terhadap kesehatan. Sebagian besar remaja mengaku tidak pernah mendengar jenis, penyebab, cara penularan dan pengobatan PMS dan AIDS. Umumnya mereka mengetahui tentang PMS melalui teman atau media massa. Dan dari teman sebaya. Rendahnya pengetahuan ini bisa menyeret remaja untuk melakukan kegiatan seksual di luar perkawinan yang akhirnya 
berdampak terjadinya kehamilan di luar perkawinan.

Rendahnya pemahaman tentang kesehatan reproduksi berdampak pada kurangnya pemahaman tentang perkawinan usia dini yang sampai saat ini masih menduduki angka yang cukup tinggi di Indonesia, perkawinan usia dini adalah perkawinan yang berlangsung saat usia kedua pasangan belum menginjak 19 tahun untuk laki-laki dan 16 tahun untuk perempuan (UU No 1 tahun 1974 tentang perkawinan) dan dalam UU No 16 tahun 2019 yang merupakan perubahan terhadap UU No 1 tahun 1974 bahkan menyantumkan usia perkawinan 19 tahun untuk perempuan dan untuk laki-laki, sehinngga ada perbedaan definisi tentang perkawinan usia dini setelah 2019 berarti saat perkawinan berlangsung usia kedua pasangan belum menginjak 19 tahun.

Perkawinan usia dini menimbulkan berbagai dampak dari mulai terganggunya kesehatan reproduksi sampai tingginya Angka Kematian Ibu. Dampak lain menurut Jesica Tiara, 2019 dalam penelitiannya, mudahnya terjadi

penelantaran dalam rumah tangga bisa menimbulkan ancaman pidana sesuai UndangUndang RI No 23 tahun 2004 tentang Kekerasan Dalam Rumah Tangga, selain itu perkawinan usia dini akan menimbulkan perceraian yang memiliki akibat hukum terlantarnya anak sehingga terjadi pelanggaran terhadap Undang-Undang Ri No 23 Tahun 2002 tentang Perlindungan Anak. Berdasarkan latar belakang tersebut di atas penulis tertarik untuk melakukan kajian literatur review dengan judul "Pemahaman Remaja Tentang Kesehatan Reproduksi Dan Tinjauan Yuridis Perkawinan Usia Dini Dilihat Dari UndangUndang Republik Indonesia Nomor 16 Tahun 2019 Tentang Perubahan Atas UndangUndang Nomor 1 Tahun 1974 Tentang Perkawinan"

\section{Metode Penelitian}

Jurnal Health Sains Vol. 2, No. 2, Februari 2021
Penelitian ini bertujuan untuk
menyajikan hasil temuan dengan menggunakan sistematik review mengikuti Panduan Pilihan untuk ulasan Sytematic Review dan Meta Analyses (PRISMA) dengan menggunakan flowchart berdasarkan daftar periksa PRISMA 2009, yaitu dengan menghilangkan artikel yang tidak relevan dengan menggunakan kriteria inklusi, penyaringan, kelayakan, dan pengunduhan akhir artikel yang relevan (Moher et al., 2009).

Strategi Pencarian: Artikel-artikel yang dicari di database secara online adalah artikel terkait dengan pemahaman remaja tentang kesehatan reproduksi yang terjadi di Indonesia dan dampaknya terhadap kesehatan reproduksi perempuan, dan artikel terkait perkawinan usia dini dilihat dari Undang-undang Perkawinan yang disajikan oleh peneliti sebelumnya untuk disajikan sebagai laporan "sistematik review yang penulis lakukan". Langkah pertama adalah mencari artikel-artikel terkait di Google scholar kemudian membuka koleksi dan memilih database secara online, dan membuka setiap basis data satu per satu. Dengan menggunakan mesin telusur dengan kata kunci "remaja, kesehatan reproduksi, dan perkawinan usia dini. Kemudian diambil artikel yang sesuai dengan kriteria inklusi dokumen yang dianggap tepat untuk melakukan sistematik review sebagai berikkut : 1) artikel yang dipublikasikan full text, 2) artikel yang diterbitkan dari tahun 2015 sampai dengan tahun 2020. 3) kriteria responden adalah remaja. 4) design penelitian qualitatif. Sedangkan untuk perkawinan dini merupakan kajian terkait dengan UU No 1 tahun 1974 tentang perkawinan. Kriteria eksklusi adalah sebagai berikut: 1) desain uji klinis; artikel yang diterbitkan kurang dari tahun 2015, 2) dampak non kesehatan. Ekstraksi dan analisis data dari setiap artikel yang dilakukan oleh penulis. Hasilnya dianalisis dan data disusun sesuai dengan analisis tema dan disusun dalam bentuk kertas narasi. 


\section{Hasil dan Pembahasan}

Penelitian mengidentifikasi 2 studi yang dimasukkan ke dalam analisis dengan rincian satu penelitian menggambarkan pengetahuan remaja tentang kesehatan reproduksi dengan metode penelitian kualitatif, data yang dikumpulkan adalah data primer hasil wawancara terhadap 2 remaja sebagai informan. Penelitian kedua merupakan penelitian hukum normative dengan menggunakan bahan-bahan hukum yang dikumpulkan melalui studi kepustakaan.

1. Hasil dari penelitian (Kurniasari et al., 2018) dengan judul "Pemahaman remaja tentang kesehatan reproduksi (pernikahan dini dan perilaku beresiko) di Sampang Madura" hasilnya menunjukkan bahwa pengetahuan remaja tentang kesehatan reproduksi masih rendah. Rendahnya pengetahuan remaja tentang kesehatan reproduksi disebabkan karena:

a. Kepatuhan remaja untuk melangsungkan perkawian di usia muda jika perkawinan itu permintaan orang tua

b. Kepatuhan remaja untuk tidak ikut menggunakan alat kontrasepsi KB jika orang tuanya tidak mengijinkan.

c. Kepatuhan remaja untuk melaksanakan persalinan di rumah, tidak di fasilitas kesehatan seperti Rumah saki, atau puskesmas

d. Remaja memiliki pendapat setuju dengan norma 'Remaja yang memiliki anak membanggakan orang tua'

e. Remaja tidak memiliki akses informasi kesehatan reproduksi dari orang tuanya melainkan dari media sosial seperti (internet, facebook) dll

f. Remaja menyetujui untuk kawin pada usia dini

g. Norma adat dan agama yang bisa menekan Perilaku beresiko seperti (pacaran dan narkoba), namun tetap memerlukan kontrol dari orang tua atau keluarga

Rendahnya pengetahuan remaja tentang kesehatan reproduksi akan menimbulkan berbagai dampak baik untuk remaja itu sendiri, keluarga, bahkan untuk masyarakat, karena ketika kita bicara tentang kesehatan reproduksi berarti kita membicarakan sebuah kelanggengan dari peradaban manusia sebagai khlaifah di muka bumi. Kesehatan reproduksi adalah suatu keadaan sejahtera fisik, mental dan sosial secara utuh, tidak semata-mata bebas dari penyakit atau kecacatan dalam semua hal yang berkaitan dengan sistem reproduksi, serta fungsi dan prosesnya (DepKes, 2007).

Hal ini tercantum dalam (UU RI No 36 tahun 2009 tentang Kesehatan pasal 71) menjelaskan : "Kesehatan reproduksi merupakan keadaan sehat secara fisik, mental, dan sosial secara utuh, tidak semata-mata bebas dari penyakit atau kecacatan yang berkaitan dengan sistem, fungsi, dan proses reproduksi pada laki-laki dan perempuan". Hak reproduksi merupakan hak asasi manusia, pemenuhannya merupakan bentuk perlindungan bagi setiap individu, serta prakondisi untuk memperoleh hak-hak lainnya tanpa diskriminasi (Syafikarani, 2018).

Ruang lingkup kesehatan reproduksi meliputi kesehatan ibu dan bayi baru lahir, keluarga berencana, pencegahan dan penanggulangan infeksi saluran reproduksi (ISR) termasuk PMS, HIV/AIDS, pencegahan dan penanggulangan komplikasi aborsi, kesehatan reproduksi remaja, pencegahan dan penanganan infertilitas, kanker pada usia lanjut dan osteoporosis, berbagai aspek kesehatan reproduksi lainnya, misalnya kanker leher rahim dan lain-lain (DepKes, 2007).

Kesehatan reproduksi remaja sebagai salah satu kesehatan yang menjadi fokus perhatian berbagai lapisan dari pemerintah tingkat pusat, daerah sampai ke tingkat Desa atau Kelurahan. Kesehatan reproduksi remaja 
merupakan salah satu usaha untuk mewujudkan remaja sehat menuju masa depan yang kuat.

Pelayanan Kesehatan reproduksi remaja tercantum dalam PP no 61 tahun 2014 BAB 1 Pasal 1 "pelayanan Kesehatan reproduksi remaja adalah salah satu kegiatan dan/atau serangkaian kegiatan yang ditujukan kepada remaja dalam rangka menjaga Kesehatan reproduksi. Bagian kedua pasal 11: (1) pelayanan Kesehatan reproduksi remaja bertujuan untuk a). mencegah dan melindungi remaja dari perilaku seksual berisiko lainnya yang dapat berpengaruh terhadap Kesehatan Repsoduksi Remaja dan b) mempersiapkan remaja untuk menjalani kehidupan reproduksi yang sehat dan bertanggungjawab".

Sebagai wujud dari Hak asasi manusia maka kesehatan reproduksi remaja ini harus betul-betul dipahami oleh remaja sejak dini untuk mempersiapkan masa depan sebuah bangsa, karena Ketika bicara tentang reproduksi berarti kita membicarakan sebuah proses biologis dari kehidupan individu untuk menghasilkan individu baru. Kesehatan reproduksi remaja merupakan kondisi kesehatan yang menyangkut masalah kesehatan organ reproduksi, yang kesiapannya dimulai sejak usia remaja dimana organ reproduksi sudah mampu melaksanakan fungsinya dengan ditandai oleh haid atau biasa disebut menstruasi pertama kali pada remaja perempuan atau mimpi basah bagi remaja lakilaki.

2. Penelitian (Mai, 2019) tahun 2019 dengan judul "Tinjauan yuridis terhadap perkawinan anak di bawah umur di lihat dari sudut pandang undang-undang nomor 1 tahun 1974" menjelaskan bahwa fenomena perkawinan di bawah umur banyak terjadi baik di daerah maupun di kota besar. Banyak anak perempuan yang dikawinkan debelum memenuhi syarat umum yang tercantum dalam UUP. Faktor yang melatarbelakangi perkawinan di bawah umurpun sangat beragam misalnya: faktor diri sendiri yang sudah saling mencintai, faktor Pendidikan orang tua, faktor ekonomi, dan faktor yang mendesak harus segera dilangsungkan perkawinan.

Akibat yuridis terjadinya pelanggaran terhadap Undang-Undang Nomor 1 tahun. 1974 tidak tampak secara jelas, karena jika perkawinan di bawah umur sudah memperoleh dispensasi, maka pelanggaran terhadap ketentuan suatu perkawinan tidak ada lagi. tetapi timbul akibat yuridis lain, yaitu terjadi penelantaran dalam rumah tangga yang bisa dikenai ancaman pidana sesuai UndangUndang Nomor 23 tahun 2004 tentang Kekerasan Dalam Rumah Tangga, selain itu jika terjadi perceraian akan timbul akibat hukum terlantarnya anak sehingga terjadi pelanggaran terhadap Undang-Undang Nomor 23 Tahun 2002 tentang Perlindungan Anak.

Rendahnya pengetahuan remaja tentang kesehatan reproduksi akan berdampak kepada masalah kesehatan itu sendiri, berbagai literatur menjelaskan seperti timbulnya perilaku seksual berisiko yang pada akhirnya menyebabkan terjadinya kehamilan tidak diinginkan, diakhiri dengan adanya aborsi tidak aman yang menimbulkan terjadinya kematian ibu karena perdarahan. Meningkatnya kasus penyakit menular seksual dan HIV/AIDS. (DAC, 2020)

Selain itu, perilaku seksual bebas pada remaja akan mendorong terjadinya perkawianan usia dini dengan diiringi berbagai dampak baik dampak fisiologis, psikologis maupun dampak kesejahteraan. Deputi Bidang Pembangunan Manusia, Masyarakat, dan Kebudayaan Kementerian Perencanaan Pembangunan Nasional (PPN)/Bappenas dalam laporan tahun 2020 melaporkan bahwa Pada tahun 2018, 1 dari 9 anak perempuan di Indonesia sudah menikah pada usia sebelum 18 tahun dengan jumlah mencapai sekitar 1.220.900, angka ini menempatkan Indonesia pada 10 negara dengan angka absolut perkawinan anak tertinggi di dunia. Rata-rata 
usia perkawinan berlangsung pada usia 15 tahun.

Perkawinan dini jika dikaitkan dengan kesehatan reproduksi perempuan sangat rentan mengalami gangguan kesehatan seperti yang disajikan dari berbagi literatur. Perkawinan dini bisa menimbulkan resiko kesehatan bagi perempuan, terutama jika terjadi kehamilan pada usia masih muda. Menurut (Manuaba, 2010) hal tersebut dikarenakan kematangan secara biologis yang belum betul-betul sempurna dapat mengakibatkan kematian saat melahirkan, dan kematangan secara pribadi juga masih belum maksimal.

Dalam artikelnya (Ariesta, 2015) yang berjudul "Sikap Remaja Putri Terhadap Pendewasaan Usia Perkawinan" Jurnal Obstretika Scientia, 2015 diunduh dari ejurnal.latansamashiro.ac.id, menjelaskan bahwa, "Secara medis perkawinan dan kehamilan pertama bagi perempuan dengan umur kurang dari 20 tahun memiliki resiko kesakitan dan kematian pada saat persalinan, atau masa nifas seperti keguguran, Preeklamsia, Eklamsia, Fistula Vesikovaginal (merembesnya air seni ke vagina), Fistula Retrovaginal, dan kanker leher Rahim, sedangkan untuk bayinya kemungkinan lahir dengan berat badan rendah. Hal ini disebabkan karena belum matangnya alat reproduksi perempaun tersebut,

Badan Kependudukan dan Keluarga Berencana Nasional (BKKBN) Jawa Barat Rabu 1/7/2020, mengampanyekan batas usia minimum bagi perempuan untuk hamil, minimal berusia 21 tahun. Hamil pada usia dini rawan potensi kelahiran Stanting dan Ibu Meninggal. Di Kabupaten Majalengka, Kepala BKKBN Jawa Barat Uung Kusman mengungkapkan, bahwa perempuan yang hamil dengan usia kurang dari 21 tahun sangat rentan dengan berbagai masalah kesehatan seperti kelahiran anak dalam kondisi Stanting. Selain itu perempuan yang melahirkan dengan usia dini merupakan penunjang tertinggi
Angka Kematian ibu yang sampai saat ini masih menjadi salah satu target pemerintah untuk menanganinya.

(Eddy Fadlyana dan Shinta Larasaty, 2016) Bagian Ilmu Kesehatan Anak FK Universitas Padjajaran/RS Dr Hasan Sadikin Bandung dalam artikelnya yang berjudul "Perkawinan Dini dan Permasalahanya" diunduh dari Sari Pediatri, 2016 saripediatri.org, menjelaskan bahwa hubungan seks pertama pada usia yang sangat muda meningkatkan risiko penyakit menular seksual dan penularan infeksi HIV, dan karsinoma serviks, sehingga akan meningkatkan angka morbiditas dan mortalitas pada remaja yang hamil. Anak yang dilahirkan dari perkawinan usia dini terjadi persaingan nutrisi dengan janin yang dikandungnya, sehingga berat badan ibu hamil sulit naik, disertai dengan anemia karena defsiensi nutrisi, berisiko melahirkan bayi dengan berat lahir rendah. Sekitar $14 \%$ bayi yang lahir dari ibu berusia remaja di bawah 17 tahun adalah prematur. Anatomi panggul yang masih dalam fase pertumbuhan menimbulkan resiko terjadinya persalinan lama yang mengakibatkan kematian bayi dan kematian neonatus. Kehamilan pada usia dini akan menimbulkan depresi yang menjadi salah satu penyebab terjadinya keguguran, berat badan lahir rendah dan lainlain. Depresi juga mengakibatkan tekanan darah tinggi, sehingga menimbulkan terjadinya eklamsi yang akan mengancam kesehatan janin maupun ibu yang mengandungnya, selain itu depresi juga akan menjadi depresi postpartum yang kemungkinan melatarbelakangi terjadinya kasus seorang ibu membunuh anaknya (Hallal et al., 2012). Keterbatasan finansial, keterbatasan mobilitas dan berpendapat, mengakibatkan istri berusia muda tidak dapat mengakses layanan kesehatan sesuai kebutuhannya, sehingga mengakibatkan tingginya komplikasi maternal dan mortalitas. 
Salah satu usaha pemerintah untuk mewujudkan kesehatan reproduksi adalah dengan membentuk UU RI No 36 tahun 2009 tentang Kesehatan pasal 71 menjelaskan : "Kesehatan reproduksi merupakan keadaan sehat secara fisik, mental, dan sosial secara utuh, tidak semata-mata bebas dari penyakit atau kecacatan yang berkaitan dengan sistem, fungsi, dan proses reproduksi pada laki-laki dan perempuan". Pasal ini menunjukkan bagaimana keseriusan pemerintah dalam melindungi hak reproduksi sebagai wujud untuk memenuhi hak asasi manusia, pemenuhannya merupakan bentuk perlindungan bagi setiap individu, serta prakondisi untuk memperoleh hak-hak lainnya tanpa diskriminasi (Syafikarani, 2018).

Untuk mewujudkan kesehatan reproduksi remaja pemerintah juga mengeluarkan regulasi tentang pelayanan Kesehatan reproduksi remaja yang dicantumkan dalam PP no 61 tahun 2014 BAB 1 Pasal 1 "pelayanan Kesehatan reproduksi remaja adalah salah satu kegiatan dan/atau serangkaian kegiatan yang ditujukan kepada remaja dalam rangka menjaga Kesehatan reproduksi”. Bagian kedua pasal 11: (1) "pelayanan Kesehatan reproduksi remaja bertujuan untuk a). mencegah dan melindungi remaja dari perilaku seksual berisiko lainnya yang dapat berpengaruh terhadap Kesehatan Repsoduksi Remaja dan b) mempersiapkan remaja untuk menjalani kehidupan reproduksi yang sehat dan bertanggungjawab".

Pada pembahasan ini dapat digambarkan bagaimanapun regulasi disusun dengan lengkap untuk mencapai kesehatan reproduksi, namun jika para remaja belum menyadari bahwa kesehatan reproduksi adalah haknya maka cita-cita bangsa untuk membangun remaja sehat mustahil akan tercapai.

Adapun perkawinan dini dilihat dari aspek psikologis banyak dibahas oleh berbagai kalangan (Yulianti, 2010), Bagian Hukum Perdata, Fakultas Hukum, Universitas
Trunojoyo dalam artikelnya yang berjudul "Dampak yang Ditimbulkan Akibat Perkawinan Usia Dini" diunduh dari journal.trunojoyo.ac.id, menjelaskan bahwa tujuan dari perkawinan salah satunya adalah memperoleh keturunan yang baik. Hal ini tidak akan tercapai jika perkawinan berlangsung pada usia muda karena kedewasaan ibu sangat berpengaruh terhadap perkembangan anak, seorang perempuan dewasa secara psikologis akan memiliki emosi yang lebih stabil, sehingga dalam mengambil keputusan penuh pertimbangan, beda jika dibandingkan dengan para ibu muda. Ibu usia remaja belum siap untuk menjadi ibu dalam arti keterampilan mengasuh anaknya. Ibu muda ini lebih menonjolkan sifat keremajaannya daripada sifat keibuannya.

(DAC, 2020) menjelaskan bahwa usia perkawinan yang ideal adalah 21-25 tahun untuk perempuan dan 25-28 tahun untuk lakilaki. Pada usia ini organ reproduksi perempuan secara fisiologi sudah mencapai kematangan dan siap untuk melahirkan keturunan secara fisik. Laki-laki pada usia 25-28 tahun dipandang secara psikis dan fisiknya sudah kuat, sehingga dia akan mampu menopang kehidupan keluarga untuk melindungi baik psikis emosional, ekonomi maupun sosial.

Untuk mencapai kematangan usia ideal perkawinan, pemerintah sudah melakukan berbagai usaha dalam menjaga kesehatan reproduksi antara lain telah disahkannya Undang-Undang Republik Indonesia nomor 16 tahun 2019 tentang perubahan atas UndangUndang nomor 1 tahun 1974 tentang perkawinan, pada tanggal 14 Oktober 2019 oleh Presiden Joko Widodo. Adapun perubahan yang berkaitan dengan usia perkawinan adalah bunyi pasal 7 ayat (1) yang awalnya berbunyi "perkawinan hanya diizinkan apabila pihak pria mencapai umur 19 (sembilan belas) tahun dan pihak wanita sudah mencapai usia 16 (enam belas) tahun" menjadi (1) "Perkawinan hanya diizinkan apabila pria dan wanita sudah mencapai umur 19 (sembilan 
belas) tahun". Pasal 7 ayat (2) menjelaskan "Dalam hal terjadi penyimpangan terhadap ketentuan umur sebagaimana dimaksud pada ayat (1), orang tua pihak pria dan/atau orang tua pihak wanita dapat meminta dispensasi kepada Pengadilan dengan alasan sangat mendesak disertai bukti-bukti pendukung yang cukup.

Perubahan batas usia perkawinan bagi perempuan yang awalnya minimal 16 tahun menjadi 19 tahun, jika dilihat dari definisi remaja menurut organisasi kesehatan dunia (WHO) sangat sesuai dimana WHO menjelaskan bahwa remaja adalah periode usia 10 sampai 19 tahun (DAC, 2020). Kesetaraan usia minimal dalam perkawinan bagi perempuan dan laki-laki membawa angin segar bagi para remaja perempuan, karena dengan adanya perubahan ini memberikan kesempatan kepada remaja perempuan yang seringkali menjadi korban diskrimasi kesetaraan gender dalam bidang pendidikan untuk mendapatkan kesempatan mengikuti Pendidikan wajib 12 tahun. Selain kesempatan untuk mendapatkan Pendidikan, juga remaja perempuan memiliki kesempatan untuk mendapatkan haknya dalam mengoptimalkan tumbuhkembangnya, serta mendapatkan pendampingan dari orang tua secara maksimal sampai masa remaja selesai. Hal ini tentunya harus disertai kesadaran dari para remaja perempuan tersebut untuk memperoleh haknya terkait batas usia minimal perkawinan, serta pemahaman orang tua terhadap pemenuhan hak bagi putra-putrinya.

Usia minimal perkawinan 19 tahun memang belum menjadi usia yang aman untuk melahirkan jika dipandang dari segi kesehatan reproduksi, karena menurut beberapa teori usia aman pertama kali melahirkan bagi perempuan adalah 21 tahun. Hal ini juga dicantumkan dalam Program Keluarga Berencana bahwa usia melahirkan yang aman pertama kali yaitu 21 tahun. Jika dikaitkan dengan UU Perkawinan memang telah dicantumkan dalam pasal 6 ayat (2) "Untuk melangsungkan perkawinan seorang yang belum mencapai umur 21 (dua puluh satu) tahun harus mendapat izin kedua orang tua". Ayat ini memperkuat teori di atas untuk memfasilitasi agar perempuan melahirkan dalam usia aman yaitu 21 tahun.

Perkawinan bagi manusia merupakan hal yang penting, karena dengan sebuah perkawinan seseorang akan memperoleh keseimbangan hidup baik secara sosial, biologis, maupun psikologis. Perkawinan ialah ikatan lahir bathin antara seorang laki-laki dengan seorang perempuan sebagai suami isteri dengan tujuan membentuk keluarga (rumah tangga) yang bahagia dan kekal berdasarkn ketuhanan Yang Maha Esa (UU No 1 tahun 1974). Menurut Akmad Shodikin, (2012), salah satu prinsip dari perkawinan, calon suami istri harus memiliki jiwa dan raga yang dipandang sudah matang untuk mewujudkan perkawinan yang baik tanpa berakhir pada perceraian dengan menghasilkan keturunan yang baik dan sehat.

Perkawinan usia dini secara yuridis tidak menimbulkan pelanggaran terhadap UU No 16 tahun 2019 tentang perkawinan jika sudah mendapatkan dispensasi dari pengadilan, namun jika terjadi kekerasan dalam rumahtangga yang disebabkan belum matangnya emosi dari suami atau istri maka akan terjadi pelanggaran terhadap UndangUndang Nomor 23 tahun 2004 tentang Kekerasan Dalam Rumah Tangga seperti yang tercantum dalam Pasal 1 "Kekerasan dalam Rumah Tangga adalah setiap perbuatan terhadap seseorang terutama perempuan, yang berakibat timbulnya kesengsaraan atau penderitaan secara fisik, seksual, psikologis, dan/atau penelantaran rumah tangga termasuk ancaman untuk melakukan perbuatan, pemaksaan, atau perampasan kemerdekaan secara melawan hukum dalam lingkup rumah tangga". Pasal 5 "Setiap orang dilarang melakukan kekerasan dalam rumah tangga 
terhadap orang dalam lingkup rumah tangganya, dengan cara: b. kekerasan fisik; c. kekerasan psikis; d. kekerasan seksual; atau e. penelantaran rumah tangga" maka hal ini akan menimbulkan kerugian untuk perempuan yang seringnya menjadi korban dan laki-laki menjadi pelaku yang bisa diancam dengan hukuman pidana.

Jika dalam perkawinan usia dini menimbulkan terjadinya perceraian maka akan terjadi penelantaran anak yang dapat melanggar Undang-undang Republik Indonesia nomor 35 tahun 2014 tentang perubahan atas undang-undang nomor 23 tahun 2002 tentang perlindungan anak seperti bunyi Pasal 1 ayat (1) "Anak adalah seseorang yang belum berusia 18 (delapan belas) tahun, termasuk anak yang masih dalam kandungan" ayat (6) "Anak Terlantar adalah Anak yang tidak terpenuhi kebutuhannya secara wajar, baik fisik, mental, spiritual, maupun sosial" Hal ini tentunya akan menimbulkan kerugian baik bagi pasangan perkawinan usia dini sendiri, keluarganya, maupun untuk masyarakat serta lebih luasnya untuk bangsa dan negara, karena anak dan remaja merupakan aset bangsa yang sangat menentukan kualitas suatu bangsa.

\section{Kesimpulan}

Rendahnya pengetahuan remaja tentang kesehatan reproduksi remaja menimbulkan dampak seperti meningkatnya angka perkawinan usia dini, terjadinya kehamilan yang tidak diinginkan, terminasi kehamilan, lahir mati, keguguran, komplikasi selama kehamilan atau persalinan, kesuburan tinggi, kekurangan gizi, kesehatan mental (stres), gangguan kesehatan reproduksi, peningkatan terjadinya penyakit menular seksual dan HIV/AIDS.

Akibat yuridis dari perkawinan di bawah usia, tidak tampak terjadinya pelanggaran terhadap Undang-Undang Nomor 16 tahun 2019 sebagai perubahan UndangUndang Nomor tahun 1974 secara jelas, karena jika perkawinan di bawah umur sudah memperoleh dispensasi, maka pelanggaran terhadap ketentuan suatu perkawinan tidak ada lagi. tetapi timbul akibat yuridis lain, yaitu terjadi penelantaran dalam rumah tangga yang bisa dikenai ancaman pidana sesuai UndangUndang Nomor 23 tahun 2004 tentang Kekerasan Dalam Rumah Tangga, jika terjadi perceraian akan timbul akibat hukum terlantarnya anak sehingga terjadi pelanggaran terhadap Undang-undang Republik Indonesia nomor 35 tahun 2014 tentang perubahan atas undang-undang nomor 23 tahun 2002 tentang perlindungan anak.

\section{BIBLIOGRAFI}

Ali, S., Stone, M. A., Peters, J. L., Davies, M. J., \& Khunti, K. (2006). The Prevalence Of Co-Morbid Depression In Adults With Type 2 Diabetes: A Systematic Review And Meta - Analysis. Diabetic Medicine, 23(11), 1165-1173.

Ariesta, R. (2015). Sikap Remaja Putri Terhadap Pendewasaan Usia Perkawinan. Jurnal Obstretika Scientia, 1(1), 33-40.

Bappenas, B. P. S. (2013). Unfpa. Indonesia Population Projection 2010-2035. Janarta: Bps.

Dac, R. (2020). Kesehatan Repsoduksi Remaja Dan Wanita: Pt Pustaka Baru, Yogyakarta.

Depkes, R. I. (2007). Pedoman Pelayanan Antenatal. Jakarta: Direktorat Bina Pelayanan Medik Dasar, Direktorat Jenderal Bina ....

Eddy Fadlyana Dan Shinta Larasaty. (2016). Perkawinan Dini Dan Permasalahanya, Bagian Ilmu Kesehatan Anak Fk Universitas Padjajaran/Rs Dr Hasan Sadikin Bandung Diunduh Dari Sari Pediatri, 2016 Saripediatri.Org.

Fitriani, S., Nurdin, M. M., Ramadhanti, H. A., Subekti, I., Nurhasanah, N., \& Yusup, I. 
F. (2020). Pembentukan Dan Pelatihan Duta Anti Rokok Pada Komunitas Saka Bakti Husada Di Smk Kesehatan X Kota Tasikmalaya Tahun 2019. Jurnal Abdimas Kesehatan Tasikmalaya, 2(02), 47-51.

Hallal, P. C., Andersen, L. B., Bull, F. C., Guthold, R., Haskell, W., Ekelund, U., \& Group, L. P. A. S. W. (2012). Global Physical Activity Levels: Surveillance Progress, Pitfalls, And Prospects. The Lancet, 380(9838), 247-257.

Kurniasari, N. D., Hariastuti, I., \& Pardiono, P. (2018). Pemahaman Remaja Tentang Kesehatan Reproduksi (Pernikahan Dini Dan Perilaku Beresiko) Di Sampang Madura. Jurnal Komunikasi, 12(1), 7485.

Mai, J. T. (2019). Tinjauan Yuridis Terhadap Perkawinan Anak Di Bawah Umur Di Lihat Dari Sudut Pandang UndangUndang Nomor 1 Tahun 1974. Lex Crimen, 8(4).

Manuaba, I. B. G. (2010). Ilmu Kebidanan, Penyakit Kandungan Dan Keluarga
Berencana. Jakarta: Egc, 15, 157.

Moher, D., Liberati, A., Tetzlaff, J., Altman, D. G., \& Group, P. (2009). ReprintPreferred Reporting Items For Systematic Reviews And MetaAnalyses: The Prisma Statement. Physical Therapy, 89(9), 873-880.

Syafikarani, A. (2018). Re-Aktualisasi Tato Pada Iklan A Mild "You Will Figure It Out" Dalam Membentuk Positioning Produk. Dekave, 11(2), 1-13.

Yulianti, R. (2010). Dampak Yang Ditimbulkan Akibat Perkawinan Usia Dini. Pamator Journal, 3(1). 